\title{
The Determinants of Foreign Exchange Reserves: Evidence from Indonesia
}

\author{
Kurnia ANDRIYANI ${ }^{1}$, Taufiq MARWA ${ }^{2}$, Nazeli ADNAN ${ }^{3}$, Muizzuddin MUIZZUDDIN ${ }^{4}$ \\ Received: August 01, 2020 Revised: October 05, 2020 Accepted: October 15, 2020
}

\begin{abstract}
This study aims to identify and analyze the factors that affect foreign exchange reserves in Indonesia. We consider the variables of external debt, exchange rate, inflation, and exports as explanatory factors referring to previous studies. We apply the Autoregressive Distributed Lag approach to time-series data retrieved from the Central Bank of Indonesia (BI), the Central Bureau of Statistics (BPS), and International Monetary Funds (IMF) from January 2016 to December 2018. Our results show that foreign debt, exchange rates, inflation, and exports significantly affect the simultaneous fluctuation of foreign exchange reserves in Indonesia. Partially, foreign debt has a significant and positive effect on foreign exchange reserves. The exchange rate has a significant and negative effect on foreign exchange reserves in Indonesia. However, our findings explain that inflation does not significantly affect foreign exchange reserves in Indonesia, and exports have a significant and positive effect on foreign exchange reserves. This study is expected to be useful to policymakers in managing foreign exchange reserves, so the economy of Indonesia can grow sustainably. One of the exciting things in this study lies in the model that uses the Autoregressive Distributed Log, which can explain long-term relationships through adjusted coefficient and cointegration tests.
\end{abstract}

Keywords: Foreign Exchange Reserves, Foreign Debt, Exchange Rate, Inflation, Export

JEL Classification Code: E52, F31, H63, P24

\section{Introduction}

Foreign exchange reserves are an essential aspect of the economy in each country. The growth and size of reserves serve as signals for global financial markets regarding the credibility of a country's monetary policy and creditworthiness. Based on the concept of international reserves and foreign currency liquidity (IRFCL) issued by the IMF (2013), foreign exchange reserves are all foreign assets controlled by the monetary authority and can be used at any time. It is further explained that these reserves are a

${ }^{1}$ First Author. Economics Department, Faculty of Economics, Universitas Sriwijaya, Indonesia. Email: nia150598@gmail.com

${ }^{2}$ Corresponding Author. Professor, Department of Economics, Faculty of Economics, Universitas Sriwijaya, Indonesia [Postal Address: JIn Inderalaya-Prabumulih, Rektorat Kampus Universitas Sriwijaya, KM 32, Inderalaya, Ogal llir, Sumatera Selatan, 30662, Indonesia] Email: taufiqmarwa@unsri.ac.id

${ }^{3}$ Lecturer, Department of Economics, Faculty of Economics, Universitas Sriwijaya, Indonesia. Email: nazeli.adnan@yahoo.co.id ${ }^{4}$ Lecturer, Department of Management, Faculty of Economics, Universitas Sriwijaya, Indonesia. Email: muizzudin@unsri.ac.id

(c) Copyright: The Author(s)

This is an Open Access article distributed under the terms of the Creative Commons Attribution Non-Commercial License (https://creativecommons.org/licenses/by-nc/4.0/) which permits unrestricted non-commercial use, distribution, and reproduction in any medium, provided the original work is properly cited. tool to finance imbalances in the balance of payments or the context of monetary stability by intervening in the foreign exchange market and for other purposes.

Meanwhile, in the balance of payments, foreign exchange reserves are usually used to finance imports and pay foreign liabilities. On the flip side, it functions to maintain monetary stability by maintaining the exchange rate of the currency. Furthermore, the global financial crisis underlined the critical role of foreign exchange reserves as a buffer stock to prevent external shocks (Tran \& Le, 2020) and the material basis for bridging the national balance of payments deficit (Chen et al., 2007).

According to Yuliana and Pratomo (2016), to manage foreign exchange reserves, the Indonesian government has a precautionary motive. This precautionary motive emerged during the period when export promotion policies were implemented and strengthened in the period following the Asian financial crisis (AFC) and after the global financial crisis (GFC), which could impact foreign exchange conditions in Indonesia. Foreign exchange reserves in Indonesia have fluctuated, as shown in Figure 1. In January 2018 , reserves amounted to US\$131,980 billion, and then there was a decrease in February to the US $\$ 128,059$ billion until September 2018, US\$114,847 billion. In October 2018, there was an increase in the US\$115,163 billion. 


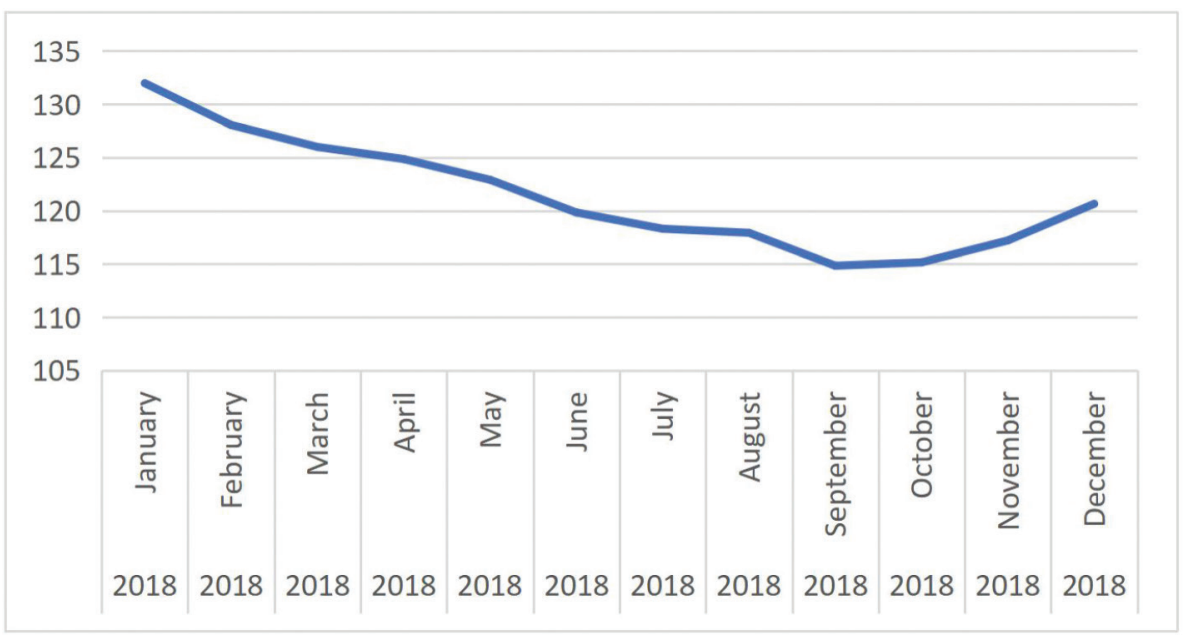

Figure 1: Foreign Exchange Reserves in Indonesia (Billion US \$)

The increase in foreign exchange reserves continued until the end of the year, in December 2018 to the US\$120,654 billion. The fluctuating foreign exchange reserves can be influenced by various factors, such as foreign debt, exchange rates, inflation, and exports. According to the Bank Indonesia (BI) Report in 2018, foreign exchange experienced a decline due to foreign debt repayment due to national development being carried out by Indonesia (BI, 2018). Foreign exchange reserves will decrease if a country pays the foreign debt, which positively influences foreign debt and foreign exchange reserves in Indonesia. Conversely, an increase in foreign exchange reserves occurs when foreign revenue increases in the form of an increase in Indonesian debt. Meanwhile, foreign exchange reserves can be affected by the exchange rate. The stronger the exchange rate shows that the country's economy is getting more established where the exchange rate is used as a means of international transactions and can affect the amount of foreign exchange held.

Further, the higher the value of a country's currency (IDR), the more foreign exchange reserves in the country. Conversely, the lower the value of a country's currency (IDR), the lower the foreign exchange reserves, so that the exchange rate positively affects foreign exchange reserves in Indonesia (Islami \& Rizki, 2018). However, there are indications that the Indonesian government is making efforts to weaken the exchange rate against the US dollar to increase the competitiveness of Indonesian exports to increase foreign exchange reserves. It is in line with the statement that the exchange rate hurts foreign exchange reserves (Azar \& Aboukhodor, 2017).

Besides, foreign exchange reserves can be affected by domestic inflation. A sustainable increase in the price of goods and services in the country can affect foreign reserves.
International trade will be affected or disrupted and may experience obstacles because the price of exported goods will be high so that demand may decline. As a result, Indonesia's revenue from exports has decreased, even imports have increased, and foreign exchange has decreased. Conversely, if inflation is low, exports will be encouraged because the prices of exported goods are low, so demand increases, and foreign exchange will increase. It is in line with the opinion that inflation hurts foreign exchange reserves (Reny \& Agustina, 2014).

Furthermore, exports can also affect foreign exchange reserves. Export is an effort to sell commodities in Indonesia to other countries with the expectation of payment in foreign currency (Tandjung, 2011). In Indonesia, exports have declined, especially in industrial exports, because human resources are not optimal. Besides, the technology used is still not sophisticated, so it is less efficient in producing goods to be exported. It is evidenced by many exports of raw goods rather than exports of finished goods to affect the amount of foreign exchange coming in. The foreign exchange obtained from exports is the foreign exchange that becomes the country's income so that when exports increase, the foreign exchange reserves can also increase.

This study analyzes various factors that affect foreign exchange reserves in Indonesia, such as foreign debt, exchange rates, inflation, and exports. We argue that these factors significantly affect fluctuations in foreign exchange reserves, as in prior studies (Ito \& McCauley, 2020; Jena $\&$ Sethi, 2020). This paper is organized into five sections. Section 2 presents a detailed review of the relevant literature explaining the determinants of foreign exchange reserves. Section 3 deals with the data and methodology. The results and interpretation are reported in Section 4. Finally, Section 5 covers conclusions. 


\section{Literature Review}

Foreign exchange reserves are a tool to avoid crises (Fischer, 2001). However, there is a limit to the number of foreign exchange reserves needed to prevent financial crises, with the fact that holding foreign reserves has implications for costs. Jovanovic and Frenkel (1981) stated that most of the regulations related to the demand for foreign exchange reserves of a country consider several variables, such as imports, exports, foreign debt, and the level of trade shocks that may occur, as well as consideration of monetary policy. In line with these theoretical reasons, Shcherbakov (2002) states that there are several general indicators used to determine the level of foreign exchange reserves for an economy. According to him, several of these indicators determine the extent of a country's external vulnerability and the ability of foreign exchange reserves to minimize this vulnerability. These indicators include import adequacy, debt adequacy, and financial adequacy.

\subsection{Foreign Debt and Reserves}

Foreign debt is assistance provided by a country from abroad with the obligation to pay it back and the loan interest within a period agreed by both parties. Usually, foreign debt and loan transactions occur when a country's income is limited and is not balanced with the need or expenditure for development costs. Therefore, revenue in a country cannot meet the desired expenditure. It has an essential role in adding to and resolving domestic shortages to accelerate the growth of savings and foreign exchange (Todaro \& Smith, 2011).

Indonesia is one of the countries that have high debt. The high foreign debt is caused by Indonesia carrying out national development. As a result, for this national development to be carried out, the government has brought in funding sources from abroad, one of which is foreign debt. Many developing countries' amount of external debt is caused by factors such as the need for funds for investment, high inflation rates, current account deficits, and structural inefficiencies in the indebted country's economy. Of these factors, the current account deficit is the leading cause of soaring foreign debt in developing countries. If every year the current transaction is hostile, foreign exchange reserves will automatically run out immediately if they do not have other sources, such as capital inflows.

The development of foreign debt can be analyzed through approaches and requests for foreign debt. The level of optimization determines the theoretical basis in funds as the degree of dependence on foreign debt. Also, foreign debt has a relationship between the level of national income (Y), domestic expenditure-in IDR (A), and the state budget deficit $(\mathrm{G})$, which can be written as follows:

$$
\text { Foreign Debt }=Y+A+G
$$

Countries that do not pay their foreign debts due to delay in paying off their foreign debts tend to experience the risk of disruptions in international trade and capital flows (Tambunan, 2001). Therefore, an increase in foreign debt tends to increase debt repayment (LS), which can be formulated in the following equation:

$$
\text { Foreign Debt }=Y+A+G+L S
$$

Foreign debt is usually in the form of foreign currency stored in foreign exchange reserves. Therefore, the higher debt a country has, the higher the foreign exchange reserves in that country. The purpose of having foreign exchange reserves is almost the same as the motive (reason) of someone having money. Foreign exchange reserves must be in the form of assets that can be easily used as needed. Meanwhile, foreign exchange reserves must be saved as the government claims to non-residents in convertible foreign currency. Limited foreign exchange owned by a country is a serious problem, resulting in dependence on other countries. If foreign exchange reserves become pseudo-foreign, they contain a lot and tend to be dominated by foreign debt. Part of this foreign debt is used to cover the current account deficit and pay principal foreign installments. The increase in foreign exchange reserves tends to increase foreign debt. In Indonesia's case, the development of foreign debt shows a positive correlation between an increase in foreign exchange reserves and an increase in foreign debt.

\subsection{Exchange Rates and Reserves}

Exchange rates are a controversial aspect of international macroeconomics. Studies show that the exchange rate plays an essential role in a country's trade performance. Exchange rate fluctuations have an essential impact on international trade, the balance of payments, and overall macroeconomic performance (Abbas et al., 2020). The exchange rate is the price of one currency in another currency (Mishkin, 2009). The foreign exchange rate is the exchange rate for the currency of another country and simultaneously shows the economic capacity of the two countries. If a country's exchange rate is greater than the exchange rate of another country, then that country's economy is more economically capable than other countries.

Conversely, if a country's exchange rate is lower than another country's exchange rate, then that country's economy is weak or less capable than other countries. The existence of this exchange rate is significant for a country in trade transactions between countries. The exchange rate is closely related to the foreign exchange reserves of the country concerned. The small amount of the company's 
foreign exchange reserves will affect the exchange rate of the country. Foreign exchange reserves are defined as all foreign assets controlled by the monetary authority and can be used at any time to pay the balance of payments balance and in the context of monetary policy stability by intervening in foreign exchange reserves and other purposes (Tambunan, 2001). Based on the above definition, foreign exchange reserves are used to maintain exchange rate stability and will also be used to pay for the balance of payments deficit.

A stable exchange rate makes all parties feel confident in the economy, and the prices of goods for raw materials are considered constant. Exchange rates can also cause appreciation and depreciation. Depreciation of a currency will cause the domestic exchange rate to weaken, resulting in difficulties in increasing foreign exchange reserves. Meanwhile, an appreciating currency causes the domestic exchange rate to strengthen and can increase foreign exchange reserves. The strengthening of the exchange rate, coupled with a stable economic condition, causes an increase in foreign exchange reserves. It is due to the encouragement of investors interested in investing in the state financial market, which will generate benefits or gains in the current account balance, thereby increasing foreign exchange reserves. (Reny \& Agustina, 2014).

The exchange rate is critical because it can affect the price of domestic goods on foreign goods' prices. The exchange rate is used to determine the purchasing power of the goods being traded. Changes in exchange rates affect the price of goods traded. If the exchange rate is high, the price of exported goods produced by that country becomes expensive and can obtain sizeable foreign exchange reserves. Conversely, if the exchange rate is low, the price of exported goods produced by that country will be low, and the foreign exchange reserves will be small. According to Sonia (2016: 108), the higher the exchange rate in a country with a strong economy, it can obtain more foreign exchange reserves. Besides, a country capable of conducting international economic and trade transactions shows sizeable foreign exchange reserves.

\subsection{Inflation and Reserves}

In the economic literature, the inflation rate is the same as the nominal money growth rate minus the economic growth rate. Over the past several decades, inflation targeting regimes have been an essential goal of central banks in several countries (Ngoc, 2020). So, the critical question is what the inflation target should be and what is the appropriate framework for the inflation target regime. In this study, we connect the inflation rate with foreign exchange reserves. We argue that inflation also affects foreign exchange reserves and economic growth in several previous theoretical and empirical works of literature. Inflation is the tendency of the prices of goods to rise generally and continuously (Roswita, 2003). Every country has a different inflation rate. If a country's inflation is higher than in other countries, then the value of that country's currency will be higher. High inflation will affect foreign exchange reserves because the funds needed are used to stabilize the value of the foreign exchange rate.

Indications of success can also be seen from indicators of stable or declining inflation. Inflation can occur because society wants to live outside the economic capacity, in which these groups of people succeed in fulfilling their desires to become enough demand for goods. In other words, the community group has succeeded in obtaining funds to change the plan to their desire to buy goods supported by existing funds. This community group maybe the government itself, which wants a larger share of society's output by making the budget deficit covered by printing new money so that a large amount of money in circulation can lead to inflation. Therefore, the government policy or the government's representatives, in changing the prices of goods in the market, indicate inflation.

The existence of stable inflation can increase foreign exchange reserves because Indonesian goods can compete abroad. However, excessive inflation will seriously harm people's daily lives. Therefore, inflation is needed in the economy at a certain level, and it is natural to grow. Economic growth can be characterized by increased production. Increased production in a country can increase foreign exchange reserves in that country. An increase in salable production means that the goods or output produced by that country could compete in the international market with goods or output produced by other countries if the price of goods produced by a country is low and fair.

\subsection{Exports and Reserves}

In the world economy, foreign exchange is significant and necessary because it serves as the primary function in supporting a country's international trade. The crisis provides a lesson that the financing of foreign exchange reserves for imports, foreign debt, and speculative behavior can destabilize the economy in Indonesia. Therefore, efforts should be made for a stable economy and increased international trade to benefit from this trade in the form of profits. Another benefit of international trade is in the form of a direct effect on the growth of domestic goods. Goods produced by one country can be sold to another country (exports). Countries with abundant natural resources, predominantly agricultural and mining commodities, encourage them to conduct international trade. For many countries, including Indonesia, international trade, especially exports, has an important role, namely, a national economy driver. For Indonesia, the export of oil and gas is 
still essential national export, not only in terms of its share of the total exports of primary commodities but also from the percentage of total national exports, namely the number of primary commodities and exports of manufacturing goods and services.

Exports are purchases of other goods made by domestic companies. The most critical factor determining exports is its ability to export goods that can compete in foreign markets. To export, a country must obtain goods and services to trade on international markets - proceeds from export sales in a foreign currency called foreign currency. The relationship between exports and foreign exchange reserves is that exporting will generate some foreign exchange, which is state income and stored in the Central Bank. If the level of exports increases, the foreign exchange reserves held will increase. If the level of exports decreases, the foreign exchange reserves they have will also decrease. If the increase in exports and imports is getting smaller $(\mathrm{X}>\mathrm{M})$, the current account will experience a surplus, and vice versa, if the decline in exports and imports is getting bigger $(\mathrm{X}<\mathrm{M})$, the current account will experience a deficit. This relationship can be written in the following equation:

\section{Current account balance $=\operatorname{export}(X)-\operatorname{import}(M)$}

Based on the above equation, the condition of foreign exchange reserves can be measured by exports. Foreign exchange reserves can increase if exports have increased from previous exports, at least two years ago. An increase in a country's exports will occur if there is a term of payment that can help buyers from abroad, and the quality of goods increases. If exports are reduced, foreign exchange reserves will decrease because foreign exchange is used and needed to pay for imports, so that imports will decrease, especially imports of capital goods, and result in reduced domestic production. Apart from exports and imports, the current account balance is also influenced by capital inflows, written as (Tambunan, 2001):

$$
\begin{aligned}
\text { Current account balance }= & (\text { Export }(X)-\operatorname{Import}(M)) \\
& + \text { Capital Inflows }
\end{aligned}
$$

The most critical objective of export activities is to make a profit. The benefits obtained are in the form of a foreign currency or foreign exchange, which will enter the balance of payments and increase the foreign exchange reserves. Exports can bring in foreign exchange, which can then be used to finance imports and economic sectors from within the country. Therefore, theoretically, it can be said that there is a positive correlation between foreign exchange reserves and export growth, import growth, domestic output growth, increased employment opportunities, and public incomes and growth in Gross Domestic Product (GDP).

\section{Data and Methodology}

\subsection{Data}

The type of data used in this study is secondary data relevant to the study in time series. Secondary data is obtained from official institutions that present and process data to be published to the public. The data sources were obtained from Bank Indonesia, the Central Bureau of Statistics (BPS), and the International Monetary Funds (IMF).

\subsection{Analysis Technique}

The analysis technique used in this research is descriptive qualitative analysis techniques and quantitative analysis techniques. Descriptive qualitative analysis is an analysis technique that describes research variables in graphs or tables and relates them to relevant theories. Meanwhile, quantitative analysis is an analytical technique that uses a statistical, mathematical, and econometric approach, especially in looking at the relationship between variables and using multiple linear regression equations using lag one can be stated as follows:

$$
\begin{aligned}
\operatorname{LnCADt}-1= & \hat{\beta} 0+\hat{\beta} 1 \operatorname{Ln} U L N_{t-1}+\hat{\beta} 2 \operatorname{Ln} \operatorname{KURS}_{t-1} \\
& +\hat{\beta} 3 \operatorname{INF}_{t-1}+\hat{\beta} 4 \operatorname{Ln} E K S_{t-1}+e_{t-1}
\end{aligned}
$$

$\mathrm{CAD}_{\mathrm{t}}$ denotes to foreign exchange reserves in Indonesia, $\mathrm{ULN}_{t}$ is foreigb debt, KURS $\mathrm{t}_{t}$ is foreign exchange, $\mathrm{INF}_{t}$ and $\mathrm{EKS}_{\mathrm{t}}$ denotes to foreign exchange and export.

\section{Results and Discussion}

\subsection{Data Descriptive}

The condition of foreign exchange reserves, external debt, exchange rates, inflation, and exports in Indonesia from January 2016 to December 2018 experienced fluctuating conditions. The highest value of foreign reserves in January 2018 was US\$131,980 billion. The lowest value of foreign reserves in January 2016 was US\$102,134 billion, while the highest foreign debt was in December 2018 of US\$377,827 billion, and the lowest foreign debt was in January 2016, amounting to US\$310,315 billion. Meanwhile, the highest exchange rate was in October 2018 with IDR15,227 per dollar, and the lowest exchange rate in September 2016 was IDR12,998 per dollar. In terms of inflation, the highest value was in December 2017 at $7.1 \%$, and the lowest inflation value was in April 2016 at $-4.5 \%$.

Furthermore, the highest export value was in July 2018, amounting to US\$16,290,204 million, and the lowest export value was in July 2016, amounting to US\$9,649,503 million. The growth of foreign exchange reserves, external debt, exchange rate, inflation, and exports in Indonesia in detail can also be seen in Figure 1, which shows the fluctuating conditions. 


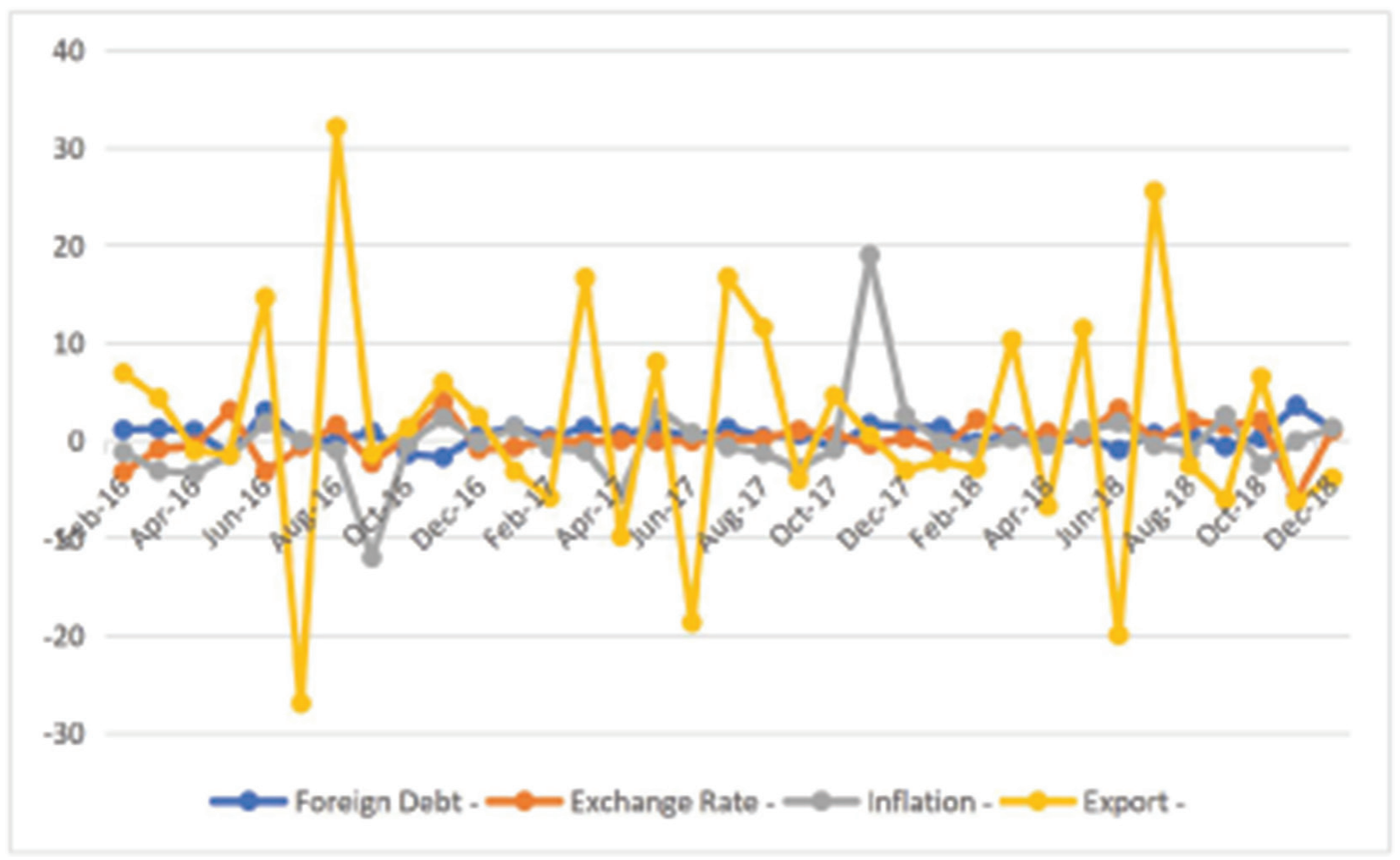

Figure 2: Foreign Exchange Reserves, External Debt, Exchange Rates, Inflation, and Exports in Indonesia

\subsection{Estimation Results}

To estimate the econometric estimate of determinants of foreign exchange reserves (foreign debt, exchange rate, inflation, and exports), we carry out a series of prerequisite tests. The two prerequisite tests include (i) stationarity test and (ii) cointegration test. The stationary test results conclude that all the indicated variables are not stationary at the level except the inflation variable, which is indicated to be stationary. Hence, it is necessary to look at the first difference level. The result of the first difference level shows that all variables are indicated to be stationary.

Therefore, testing can be carried out to the next stage, namely, the cointegration test. The results of the cointegration test can be used as a basis for determining the equations used to have a long-term balance or not. If the equations are proven to be cointegrated through the Johansen test, then the estimation equation has long-term balance. The following are the results of the cointegration test using the Johansen test. Our test results conclude that there is a cointegration equation. It implies that foreign debt, exchange rates, inflation, and exports have an influence on foreign exchange reserves in the long-term balance. We also perform a classic assumption test. It ensures that there are no statistical problems in our analysis so that the estimation results are not biased.

Furthermore, after we conducted the prerequisite test and classic assumption test, we estimated the effect of foreign debt, exchange rates, inflation, and exports on fluctuations in foreign exchange reserves in full in Table 1. Based on the estimation results, an equation model can be formed for the effect of external debt, exchange rate, inflation, and exports on fluctuations in foreign exchange reserves in Indonesia, as follows:

$\begin{aligned} \text { LnCAD }_{-1}= & -1.6767+1.0549 \text { LnULN }_{-1}-1.3420 \text { LnKURS }_{-1} \\ & +0.0006 \mathrm{INF}_{-1}+0.2319 \mathrm{LNEKS}_{-1}+0.0082 \mathrm{ECT}\end{aligned}$

Based on the estimation results, an equation model can be formed for the effect of external debt, exchange rate, inflation, and exports on fluctuations in foreign exchange reserves in Indonesia, which is obtained based on Table 3 above, as follows:

$$
\begin{aligned}
\operatorname{LnCAD}_{-1}= & -1.6767+1.0549 \mathrm{LnULN}_{-1}-1.3420 \mathrm{LnKURS}_{-1} \\
& +0.0006 \mathrm{INF}_{-1}+0.2319 \mathrm{LNEKS}_{-1}+0.0082 \mathrm{ECT}
\end{aligned}
$$


Table 1: The Estimation Results of Error Correction Model (ECM)

\begin{tabular}{|l|c|c|c|c|}
\hline Dependent Variable: LNCAD(-1)/ Lag-1 of Foreign Exchange Reserves \\
\hline Variables & Coefficient & Std. Error & T-Statistic & Probability \\
\hline C & -1.676796 & 0.065778 & -25.49174 & 0.0000 \\
\hline LNULN(-1) & 1.054996 & 0.016567 & 63.68088 & 0.0000 \\
\hline LNKURS(-1) & -1.342097 & 0.016397 & -81.84823 & 0.0000 \\
\hline INF(-1) & 0.000659 & 0.000212 & 3.110755 & 0.0942 \\
\hline LNEKS(-1) & 0.231931 & 0.006115 & 37.92756 & 0.0000 \\
\hline ECT & 0.008201 & 0.000128 & 64.02042 & 0.0000 \\
\hline Adjusted R-squared $=0.998390$ & \multicolumn{2}{|l|}{ R-squared = 0.998627} \\
\hline F-statistic = 4217.213
\end{tabular}

Note: estimation is made after conducting time-series data prerequisite tests and classical assumptions.

\subsection{Discussions}

The estimation results show that the foreign debt variable has a positive relationship to foreign exchange reserves, with the estimation results at the level of $\alpha=5 \%$. It means that an increase will follow any increase in foreign debt in foreign exchange reserves in Indonesia. It is shown by the foreign debt coefficient of 1.0549. It implies that when foreign debt increases by 1 percent, foreign exchange reserves will increase by 1.0549 percent, assuming the other independent variables are considered constant. The results of this study are in line with the theory of capital flows. This theory explains that borrowing money from other countries will lead to the circulation of foreign exchange. Countries that lend their money in the form of foreign exchange will enter the balance of payments so that Indonesia's foreign exchange reserves will increase. This research is also in line with the results of research by Deki et al. (2017), state that there is a positive effect of foreign debt on foreign exchange reserves in Indonesia.

The next variable is the dollar exchange rate against IDR. The results show a negative and significant effect on foreign exchange reserves with a coefficient of elasticity of -1.3420 and a probability value of 0.0000 . It implies that each dollar exchange rate appreciates by 1,000 points, then foreign exchange reserves will decrease by the US $\$ 1.3420$ billion, assuming other independent variables are considered constant. According to the exchange rate theory, this happens because of the capital outflow. The balance of payments is in deficit so that the IDR exchange rate against the US dollar depreciates, and the rupiah weakens. This result is in line with the research of Azar and Aboukhodor (2017) that the exchange rate has a negative and significant effect on foreign exchange reserves. However, the results of this study are not in line with Islami and Rizki (2018) reveals that the exchange rate has a positive and significant effect on foreign exchange reserves.

We also consider the inflation variable as a determinant of foreign reserves. The results show that inflation has a positive and insignificant effect on foreign exchange reserves with a coefficient value of 0.0006 and a probability value of 0.0942 . The insignificance of inflation in affecting foreign exchange reserves is due to the tendency of increasing prices for goods and services or inflation, which will hamper economic activity in the country concerned so that the country needs more foreign exchange to be able to transact abroad. As research by Putra and Indrajaya (2013) will cause a deficit in Indonesia's trade balance, which will result in a decline in Indonesia's foreign exchange reserves. If inflation occurs in a country, the prices of goods and services in that country are also high. It impacts changes in the value of the currency and current accounts with banks and foreign exchange reserves.

Finally, we also consider the export variable. The results show that exports have a positive and significant effect on foreign exchange reserves with a coefficient value of 0.2319 and a probability value of 0.0000 . It explains that each export has an increase of 1 percent, then foreign exchange reserves will increase by 0.2319 percent, assuming other independent variables are considered constant. It is following the theory of comparative advantage regarding the relationship between exports and foreign exchange reserves in conducting international trade, and the country will get an exchange rate called foreign exchange, which is one of the sources of state income. Thus, the increased export activity will increase the foreign exchange reserves held by the state. The results of this study are in line with prior literature (Benny, 2013; Rahmawati \& Setyowati, 2018; Reny \& Agustina, 2014; Sonia \& Setiawina, 2016) that exports have a positive and significant effect on foreign exchange reserves in Indonesia in the period January 2016 to December 2018. 


\section{Conclusion and Policy Implication}

Based on the results of data analysis and discussion stated, it can be concluded that the condition of foreign exchange reserves, external debt, exchange rates, inflation, and exports in Indonesia from January 2016 to December 2018 fluctuated. External debt, exchange rate, inflation, and exports significantly affect the fluctuation of foreign exchange reserves in Indonesia. External debt and export have a significant and positive effect on foreign exchange reserves in Indonesia. Meanwhile, the exchange rate has a significant and negative effect on foreign reserves, and inflation does not significantly affect foreign exchange reserves in Indonesia. Based on our research findings, we point out several policy implications, such as the government's need to increase exports because it is profitable and increases foreign exchange reserves in Indonesia. Therefore, the balance of foreign exchange reserves must be maintained by Bank Indonesia as the monetary authority in Indonesia. Besides, Central Bank or government policies require control over the stability of the rupiah exchange rate to maintain the inflation rate according to the target and safeguard Indonesia's foreign exchange reserves.

\section{References}

Abbas, S., Nguyen, V. C., Yanfu, Z., \& Nguyen, H. T. (2020). The Impact of China Exchange Rate Policy on its Trading Partners: Evidence Based on the GVAR Model. Journal of Asian Finance, Economics and Business, 7(8), 131-141. doi:10.13106/jafeb.2020.vol7.no8.131

Azar, S. A., \& Aboukhodor, W. (2017). Foreign Exchange Reserves and the Macro-economy in the GCC Countries. Accounting and Finance Research, 6(3), 16. https://doi.org/10.5430/afr.v6n3p72

Benny, J. (2013). The Effect of Exports and Imports on the Position of Foreign Reserves in Indonesia. Jurnal Riset Ekonomi, Manajemen, Bisnis dan Akuntansi, 1(4).

BI. (2018). Monetary Policy Review. Retrieved from https:// www.bi.go.id/en/publikasi/kebijakan-moneter/tinjauan/Pages/ Tinjauan-Kebijakan-Moneter-Desember-2018.aspx

Chen, D., Li, C., Xu, X., \& Lei, J. (2007). An Empirical Assessment on China's Optimal Foreign Exchange Reserve: 1985-2004. Journal of Asia Business Studies, Spring(2007), 20-26.

Deki, Marwoto, P. B., \& Marheni. (2017). Analysis of the Effect of Portfolio Investment, USD / IDR Exchange Rates, External Debt, and the Trade Balance on the Position of Foreign Exchange Reserves in Indonesia. MarheniJurnal Ilmiah Progresif Manajemen Bisnis, 16(12), 1-8.

Fischer, S. (2001). Opening Remarks by IMF First Deputy Managing Director. Retrieved from https://www.imf.org/en/ News/Articles/2015/09/28/04/53/sp042801

IMF. (2013). International Reserves and Foreign Currency Liquidity Guidelines; Guidelines for A Data Template. Washington, DC: International Monetary Fund.
Islami, H., \& Rizki, C. Z. (2018). The Effect of Interest Rates, Exchange Rates and Inflation on Indonesia's Foreign Exchange Reserves. Jurnal Ilmiah Mahasiswa Ekonomi Pembangunan, 3(1), 15. Retrieved from http://jim.unsyiah.ac.id/EKP/article/view/6875

Ito, H., \& McCauley, R. N. (2020). Currency composition of foreign exchange reserves. Journal of International Money and Finance, 102, 102104. https://doi.org/10.1016/j. jimonfin.2019.102104

Jena, N. R., \& Sethi, N. (2020). Determinants of foreign exchange reserves in Brazil: An empirical investigation. Journal of Public Affairs, e2216. doi:10.1002/pa.2216

Jovanovic, B., \& Frenkel, J. (1981). Optimal international reserves. Economic Journal, 91(362), 507-514.

Mishkin, F. S. (2009). Economics of Money, Banking, and Financial Markets. Boston, MA: Addison-Wesley.

Ngoc, B. H. (2020). The Asymmetric Effect of Inflation on Economic Growth in Vietnam: Evidence by Nonlinear ARDL Approach. Journal of Asian Finance, Economics and Business, 7(2), 143-149. doi:10.13106/jafeb.2020.vol7.no2.143

Putra, I. B. P. P., \& Indrajaya, I. G. B. (2013). The Effect of Inflation, Foreign Debt and Credit Interest Rates on Indonesia's Foreign Exchange Reserves for 1996-2011. E-Jurnal EP Unud, 2(11), 533-538.

Rahmawati, H. F., \& Setyowati, E. (2018). The Effect of Exports, Imports, Money Supply and Inflation on Indonesia's Foreign Exchange Reserves for the April 2012-June 2017 Period. The National Conferences Management and Business, 6(6), 17.

Reny \& Agustina. (2014). The Influence of Exports, Imports, Rupiah Exchange Rate, and Inflation Rate on Indonesia's Foreign Exchange Reserves. Jurnal Wira Ekonomi Mikroskil, 4(2), 10.

Roswita. (2003). Monetary Economics. Palembang, Indonesia: Penerbit Universitas Sriwijaya.

Shcherbakov, S. G. (2002). Foreign Reserves Adequacy: Case of China. IMF. Canberra, Australia.

Sonia, A. P., \& Setiawina, N. D. (2016). The Influence of Exchange Rates, Money Supply and Inflation Rate on Indonesia's Exports, Imports and Foreign Exchange Reserves. E-Jurnal Ekonomi Pembangunan Universitas Udayana, 5(26), 1077.

Tambunan, T. (2001). International Trade and the Balance of Payments: Theory and Empirical Findings. Jakarta, Indonesia: PT. Pustaka LP3ES Indonesia.

Tandjung, M. (2011). Export-Import Aspects and Procedures. Jakarta, Indonesia: Salemba Empat.

Todaro, M. P., \& Smith, S. C. (2011). Development Economics. Jakarta, Indonesia: Erlangga.

Tran, T. V., \& Le, T. P. T. D. (2020). Optimum Reserves in Vietnam Based on the Approach of Cost-Benefit for Holding Reserves and Sovereign Risk. Journal of Asian Finance, Economics and Business, 7(3), 157-165. doi:10.13106/jafeb.2020.vo17.no3.157

Yuliana, \& Pratomo, Y. (2016). The Indonesian Government's Motives in Managing Foreign Exchange Reserves. Bina Ekonomi, 20(0298), 67-75. 